Corresponding Author: Novita Novita; email:

noevitastikes@gmail.com

Published: 7 February 2022

Publishing services provided by Knowledge E

(c) Novita Novita, and Reno

Prasetyo. This article is

distributed under the terms of

the Creative Commons

Attribution License, which

permits unrestricted use and

redistribution provided that the

original author and source are credited.

Selection and Peer-review unde the responsibility of the IVCN Conference Committee.

\section{The Influence of Nurse Competence and Performance on Quality of Service and Patient Satisfaction}

\section{Novita Novita* and Reno Prasetyo}

Sekolah Tinggi Ilmu Kesehatan Abdi Nusantara

\section{ORCID}

Novita Novita: https://orcid.org/0000-0001-6902-958X

Abstract. Nursing care is significant in determining the quality of service in hospitals, and one of the indicators of service quality is patient satisfaction. This study aimed to determine the effect of nurse competence and performance on service quality and patient satisfaction. This was a quantitative cross-sectional study, and data were analyzed using path analysis t-test. There were 100 respondents and data collection was through interviews. This research was conducted at the Pusdikes Hospital in Jakarta. The factors that affected satisfaction were performance $(p=0.042)$ and service quality ( $p<0.001$ ). Competence, performance, and service quality also affected satisfaction in combination ( $p<0.001)$. The variables that affected service quality were competence ( $p<0.001$ ) and performance $(p=0.004)$. Furthermore, competence and performance also had a simultaneous effect on quality $(p<0.001)$.

Keywords: competence, nurse performance, service quality, patient satisfaction

\section{Introduction}

According to Law number 44 of 2009, the hospital is a health service institution that provides complete individual health services by providing inpatient, outpatient, and emergency services. Hospitals in their management as managers of health services need management that can run according to the vision and mission that is carried out. Hospitals are expected to provide services that create benefits for their customers [1].

The increasingly fierce competition between hospitals and health service providers requires each hospital to have a comparative advantage compared to other hospitals in order to be able to compete well. Hospital advantages can be in the totality of services or specific services that are "not owned" or "have advantages" compared to other hospitals. This advantage will ultimately provide more value for a hospital and be sought after by customers/patients who are increasingly selective in obtaining health services [2].

Changes in people's consumption patterns affect the public's perspective on the S OPEN ACCESS 
responsive to existing health phenomena, and the level of public expectations is increasing. The community wants the provision of quality and fast services. One of the service units in hospitals that is often in the spotlight is the inpatient service unit. In this unit, the community often has to face long-standing competencies in obtaining services and the availability of drugs which are often associated with the quality of inpatient services and patient satisfaction [3].

In order to improve development in the quality and efficient inpatient services based on pharmaceutical care in hospitals, it is necessary to have a service standard that can be used as a guide in providing inpatient services in hospitals. Minimum Service Standards (MSS) for health services in hospitals are critical because they are a benchmark for health services organized by hospitals. According to the Decree of the Minister of Health of the Republic of Indonesia No.129 of 2008, the standard indicators for inpatient service hospital services are the competence of ready-to-use drugs 30 minutes and concoction drugs 60 minutes, 100\% drug administration errors, customer satisfaction $80 \%$, and prescription writing according to the formulary is $100 \%$ [4]

Inventory is one of the things of concern in logistics management. The existence of inventory based on this definition indicates that inventory is an item provided by the organizer or logistics officer to be used if there is a demand for goods. Regulation of the Minister of Health of the Republic of Indonesia, Number 35 of 2014 concerning Standards for Inpatient Services Article 3 paragraph (2), states that the management of inpatient preparations, medical devices, and medical consumables as intended includes: planning, procurement, receipt, storage, destruction, control, recording, and reporting. Hospital inpatient services are an inseparable part of the hospital health service system oriented to patient care, providing quality drugs, including inpatient clinic services that are affordable for all levels of society.

Given the significant contribution of inpatient installations in the smooth running of services, the supply of inpatient goods requires a careful and responsible management of managerial activities. The administrative function plays a critical role in managing the inpatient installation itself [5]. Inpatient care is a form of service and direct responsibility of the pharmacist profession in inpatient work to improve patients' quality of life. Inpatient care is a collaborative process that aims to identify, prevent and resolve drug problems and health-related problems [6]. Two critical elements in efforts to improve inpatient services are patient satisfaction as service users and the fulfillment of established service standards [7]. 
To improve the quality of inpatient services, hospitals must increase the commitment, awareness, and ability of workers, especially those who have direct contact with consumers. Even though the quality system and technique are sound, if the people who implement it and the tools used are incorrect, the expected quality of service will not be realized. All personnel involved in the management of health organizations have the same role and function, namely working hand in hand in serving the community. To coordinate and organize all elements in the system, proper management is needed and tailored to the needs. In addition, the increasing number of patients impacts the length of waiting time required to obtain health services, so that patients often complain about the length of competence. Performance and duration of competence are two factors that influence the quality of service and its impact on patient satisfaction. Health care for patients (customer service) is often fought for at this time by all health care institutions, both private and government, considering the great competition among health service providers. This can be seen from the level of patient satisfaction. If the patient is satisfied with the services provided, they will return to using existing health service facilities or even recommend it to others. However, if the patient is not satisfied, then, on the contrary, the possibility is that the patient will not visit again when sick and even recommend to other parties [8].

The report obtained from the Pusdikes Hospital on the management of the Pusdikes Hospital shows that the quality of service in this hospital has not been maximized, the results of patient satisfaction by the hospital show that patients who are satisfied with the quality only reach $40.0 \%$, based on the facts above, it is very It is crucial to organize a study to examine factors related to quality and patient satisfaction. The purpose of this study was to determine the effect of competence and performance on service quality and to pay attention to patients in the Outpatient Unit at the Pusdikes Hospital in 2020.

\section{Methods}

\subsection{Design}

The approach to this research design is a quantitative analytical survey using a crosssectional study approach, meaning that the sampling method for risk and effect factors is carried out simultaneously (simultaneously). 


\subsection{Sample}

This research was conducted at the Pusdikes Hospital, Jalan Raya Bogor Number 20 Kramat Jati ( Jaktim) DKI Jakarta, carried out for four months, namely January 2020 April 2020. The number of samples in this study was 100 respondents.

\subsection{Procedure}

The design used in this study is a parametric statistical approach (requirements: the data must be in numeric form) with a correlation regression research design, which connects exogenous-intervening and endogenous variables. This research will be combined with a Path Analysis approach, which analyzes the relationship based on path analysis, a statistical analysis technique developed from multiple regression analysis. The statistical test used is the t-test, considering that the variation in the data is categorized in the form of an interval scale.

\subsection{Questionnaire for Data Collection}

The development model is exogenous variables: competence and performance (symbolized by $X 1$ and $X 2$ ), then associated with service quality $(Y)$, and subsequently associated with patient satisfaction (Z).

\subsection{Data Analysis}

The data were analyzed by SPSS/WIN version 23. Descriptive statistics were used to explain the respondents' demographic information, as well as other research variables. A Chi-square test was used to find the relationship between variables. The $p$-value $<$ .05 was considered significant.

\section{Results}

\subsection{Research Hypothesis Testing}

Path analysis method (path analysis) is used in testing the magnitude of the contribution indicated by the path coefficient on each path diagram of the causal relationship between variables $X 1, X 2, Y$ to $Z$. to determine the degree of relationship between 
TABLE 1: Recapitulation of Results of Analysis of Direct and Indirect Effects Between Competence, Performance, Quality of Service and Patient Variables at the Jakarta Health Center Hospital

\begin{tabular}{|c|c|c|c|c|}
\hline \multirow[t]{2}{*}{ Causal Relationship } & \multicolumn{3}{|c|}{ The magnitude of Causal Relationship } & \multirow[b]{2}{*}{ Sig. } \\
\hline & Direct & Indirect & Total & \\
\hline X1 To Z & 0,122 & & 0,122 & 0,122 \\
\hline $\mathrm{X} 1 \mathrm{To} Z$ through $\mathrm{Y}$ & & $0,122+(0,604 \times 0,566)$ & 0,463 & - \\
\hline X2 To Z & 0,180 & - & 0,180 & 0,180 \\
\hline$X 2$ To $Z$ through $Y$ & & $0,180+(0,248 \times 0,566)$ & 0,320 & - \\
\hline Y To Z & 0,566 & - & 0,566 & 0,566 \\
\hline$X 1$ and $X 2$ and $Y$ to $Z$ & 0,635 & - & 0,635 & 0,635 \\
\hline X1 To Y & 0,604 & - & 0,604 & 0,604 \\
\hline X2 To $Y$ & 0,248 & - & 0,248 & 0,248 \\
\hline$X 1$ and $X 2$ To $Y$ & 0,626 & - & 0,626 & 0,626 \\
\hline
\end{tabular}

Competence (X1), Performance (X2), and Service quality $(Y)$ on patient satisfaction ( $\mathrm{Z})$ was carried out by distributing a closed questionnaire. The analysis used a correlation technique which is the basis for calculating the path coefficient. This test will be carried out through 2 stages of analysis, namely comprehensive testing (model 1) and individual testing (model 2).

\section{Discussion}

\subsection{The Direct Effect of Competence on Patient Satisfaction}

Patient satisfaction is the primary indicator of the standard of a health facility and is a measure of service quality. If low satisfaction impacts the number of visits, that will affect the profitability of the health facility. One of the factors that influence satisfaction is the competence of health workers.

In this study, an analysis was also carried out to determine the effect of officer competence on patient satisfaction, and the results obtained a coefficient value of pzx1 $=0.122$, which means that the contribution is $12.2 \%$, and the value of sig. 0.241 ( $p$-value $>$ alpha 0.05), meaning that statistically, the competence factor does not contribute positively to patient satisfaction, or the influence of competence is not significant on patient satisfaction at the Pusdikes Hospital.

The results of this study are in line with research conducted by [9], showing that competence does not affect patient satisfaction. The competency indicators assessed by respondents in this study include education, training, and others. Patients still feel dissatisfied with the attitude of nurses in providing services, and patients still feel that 
nurses have not been able to meet patient needs optimally. In other words, respondents' responses to nurses' attitudes have not been positive, and there is still a need for improvement.

\subsection{The Direct Effect of Nurse Performance on Patient Satisfaction}

In this study, the researcher also analyzed the effect of performance on patient satisfaction, and the results showed that the coefficient value of $p z \times 2=0.140$. While the value of sig 0.042 , because the value of sig 0.042 is smaller than the probability value of 0.05 or a value of $0.05>0.042$, it means that the contribution of performance to patient satisfaction at the Pusdikes Hospital is significant, the contribution is 14.0\%. [10], regarding the Relationship of Nurse Performance to Patient Satisfaction Levels, that nurse performance affects patient satisfaction $(p$-value $=0.008)$. In addition, research by Heather Farley, MD*; [11] entitled Patient Satisfaction Surveys and Quality of Care: An Information Paper suggests that performance is related to patient satisfaction.

\subsection{Direct Effect of Service Quality on Patient Satisfaction}

In this study, an analysis was also carried out to determine the effect of service quality on patient satisfaction, the coefficient value of $p z \times 3=0.566$ and sig value of 0.000 , meaning that there is a significant influence between quality on patient satisfaction at the Pusdikes Hospital, the contribution is $56.6 \%$.

This study is in line with the research conducted by [12] regarding: "Outpatient Satisfaction Service Quality" that the quality dimensions that affect patient satisfaction are reliability and assurance dimensions. Then the research of John E Ware et al. (2015) also revealed the significance of the influence of service quality on patient satisfaction.

In the research of [13] stated that quality has a significant influence on patient satisfaction. In addition, research by [14] on the Effects of hospital service quality on patients satisfaction and behavioral intention of doctors and nurses explain that service quality contributes to patient satisfaction in obtaining health services in hospitals. The better the quality, the better the satisfaction. Therefore, Pusdikes Hospital needs to improve the quality of its services from various dimensions so that patients feel good service so that their satisfaction can be fulfilled. 


\subsection{The Effect of Simultaneous Competence and Performance of Nurses on Service Quality in Inpatient Installations at the Pus- dikes Hospital in 2020.}

The analysis results show that the coefficient value of $p z y \times 1 \times 2=0.635$ and sig value of 0.000 ( $p$-value < alpha 0.05), meaning that Ho is rejected and $\mathrm{Ha}$ is accepted, meaning the path analysis coefficient is significant. This means that competence, nurse performance, and service quality simultaneously contribute significantly to patient satisfaction at the Pusdikes Hospital. The contribution value is $63.5 \%$. The remaining $36.5 \%$ is influenced by other factors that cannot be explained in the study (other factors can be in the form of service prices, access, the possibility of patients recovering, distance from home to hospital, facilities, and others).

In his research, [15] stated that the factors that influence patient satisfaction are the performance of health workers, attitudes, competencies, the expertise of health workers, service quality, waiting time, costs, and health insurance. In addition, research by [13] in Lebanon states that the elements that influence patient satisfaction are the level of education, patient age, and service quality.

In this analysis, the researcher assumes that from $70.9 \%$ of other factors that affect patient satisfaction, there are patient characteristics, such as age, education, and occupation of the respondent. This study led to the results of univariate analysis, which aims to describe the characteristics of the respondents.

\subsection{The Direct Effect of Competence on Service Quality}

The results of the path analysis show that the coefficient value of pyx $1=0.604$ and sig value of 0.000 (p-value < alpha 0.05 ), meaning that $\mathrm{Ho}$ is rejected and $\mathrm{Ha}$ is accepted, the conclusion is that the path analysis coefficient is significant. This means that the nurse's competence factor contributes significantly to the quality of service. The conclusion is that there is a significant influence between the competence of nurses and the quality of service at the Pusdikes Hospital.

The results of this study are different from [16] about showing that the factors that affect the quality of services in hospitals, including the nurse competence factor, are related to the quality of services in health facilities. In another study conducted by [17] stated that the participants' most significant discomfort was with the time spent in the facility. The patient's attitude will change if the waiting time allocated for waiting at the health facility is long. The patient's attitude will change in line with the conditions in 
the field. Likewise, the attitude of health workers who do not care about patients will reduce the quality of their services.

Research by [18] on Patient satisfaction with hospital care and nurses in England: an observational study suggests that patient perceptions of care are significantly eroded by a lack of trust in either nurses or doctors.

\subsection{Direct Effect of Performance on Service Quality}

The previous analysis of the influence between performance and satisfaction showed a significant correlation. In this section, regarding the influence between performance and service quality, the result is a coefficient value of pyx $2=0.248$ and a sig value of 0.004 (p-value < alpha 0.05), meaning $\mathrm{Ho}$ is rejected and $\mathrm{Ha}$ is accepted, meaning the path analysis coefficient is significant. So, the performance factor contributes to the quality of service. The conclusion is that there is a significant influence between the performance factor and the quality of service at the Pusdikes Hospital. The contribution is $24.8 \%$.

[19] research on Service quality in hospitals shows a significant influence between knowledge, attitude, and performance on service quality. In addition, [18] research on: "Service Quality in Hospitals and Factors Affecting It" also shows an influence between leadership, competence, performance, knowledge, attitudes, and health service facilities on service quality.

Research [11] on Patient Satisfaction Surveys and Quality of Care, suggested that patient experience is used as a surrogate marker for the quality and value of health care delivery, performance related to experience, programs and effects on emergency treatment, discuss the literature describing the relationship between quality and patientreported experience, and discuss future opportunities for emergency medicine.

\subsection{The Simultaneous Effect of Competence and Performance of Nurses on Service Quality}

Individually, only the performance of nurses contributed significantly to the quality of service. However, simultaneously competence and performance contributed $62.6 \%$. Other factors influence the remaining 37.4\% explained in this study, such as leadership, competence, access, and facilities. 


\subsection{Indirect Effect of Competence on Patient Satisfaction}

The influence of competence is directly on patient satisfaction. This variable also indirectly contributes strongly to satisfaction. The value of its contribution is $46.3 \%$. That is, if competence is juxtaposed with quality, it will affect $62.6 \%$ in influencing patient satisfaction. In other words, patients will be more satisfied if the competence is good and the quality of service is excellent, and vice versa.

\subsection{Indirect Effect of Performance on Patient Satisfaction}

Directly performance also contributes significantly to patient satisfaction. Indirectly, the performance also contributes $32.0 \%$ to patient satisfaction. The performance of nurses needs to be improved to improve the quality of service, which will impact increasing patient satisfaction. If the nurse performs well, the quality of service will increase, and the impact will increase patient satisfaction.

\section{Funding}

We Declare no funding for this study.

\section{Conflict of Interest}

We declare no conflict of interest.

\section{References}

[1] Fauzi, F. Hospital service quality in the new era. Jakarta: Indopos Jakarta.

[2] Hasibuan MSP, Hasibuan HMSP. Manajemen sumber daya manusia. Bumi Aksara; 2016.

[3] Supriyanto SE. Pemasaran industri jasa kesehatan. Yogyakarta: 2010.

[4] Indonesia Ministry of Health. Decree of the Minister of Health of the Republic of Indonesia no.129/menkes/SK/II/2008. Indonesia Ministry of Health; 2008.

[5] Noviani W. Persepsi mahasiswa profesi ners tentang kode etik keperawatan indonesia di rumah sakit pendidikan Universitas Muhammadiyah Yogyakarta. IJNP (Indonesian Journal of Nursing Practices). 2016;1:30-39. 
[6] Depkes. Pedoman nasional penanggulangan tuberkulosis. 2016. DOI: 616.995.24 Ind $\mathrm{P}$

[7] Azwar S. Human attitude: Theory and its measurement. Yogyakarta: Student Lit.

[8] Nursalam D. Manajemen keperawatan aplikasi dalam praktik keperawatan profesional.

[9] Gerlinger G, Hauser M, de Hert M, et al. Personal stigma in schizophrenia spectrum disorders: A systematic review of prevalence rates, correlates, impact and interventions. World Psychiatry. 2013;12:155-164.

[10] Simorangkir RM, Thomson T, Hadi AJ. Relationship on nursing performance of patient satisfaction in installation of hospital in general hospital deli serdang region. International Journal of Research in Medical Sciences.

[11] Farley $\mathrm{H}$, Enguidanos ER, Coletti CM, et al. Patient satisfaction surveys and quality of care: An information paper. Annals of Emergency Medicine. 2014;64:351-357.

[12] Kamchuchat C, Chongsuvivatwong V, Oncheunjit S, et al. Workplace violence directed at nursing staff at a general hospital in southern Thailand. Journal of Occupational Health. 2008;50:201-207.

[13] Ammo MA, Abu-Shaheen AK, Kobrosly S, et al. Determinants of patient satisfaction at tertiary care centers in Lebanon. The Open Nursing Journal. 2014;4:939.

[14] Maqsood M, Maqsood H, Kousar R, et al. Effects of hospital service quality on patients satisfaction and behavioural intention of doctors and nurses. Saudi Journal of Medical and Pharmaceutical Sciences. 2017;3:556-567.

[15] Ware Jr JE, Snyder MK, Wright WR, et al. Defining and measuring patient satisfaction with medical care. Evaluation and Program Planning. 1983;6:247-263.

[16] Georgia G, Martha K, Georgia G, et al. Quality of life of patients undergoing hemodialysis. Journal of Health Research

[17] Bamidele AR, Hoque ME, Van Der Heever H. Patient satisfaction with the quality of care in a primary health care setting in Botswana. South African Family Practice. 53.

[18] Aiken LH, Sloane DM, Ball J, et al. Patient satisfaction with hospital care and nurses in England: An observational study. BMJ Open. 2021;8:e019189.

[19] Sohail MS. Service quality in hospitals: More favourable than you might think. Managing Service Quality: An International Journal 